\title{
The Using of Ethical Resource - Based Learning to Develop Ethical Information Literacy and Moral Behavior
}

\author{
Titiya Netwong and Ratchadaphorn Thirawan
}

\begin{abstract}
The objectives of this research were: 1) to study the implementation of ethical resource - based learning enhancing ethical information literacy and moral behavior, and 2) to develop ethical information literacy and moral behavior of students in the program of Information Technology. The sample consisted of 38 undergraduate students of Information Technology Department who registered the course of information integration, in 2015 academic year. The research instruments were the ethical information literacy questionnaire and moral behavior questionnaire. The data was statistically analyzed by mean, standard deviation and t-test for dependent samples. The results of the study were as follows: 1) Ethical information literacy and moral behavior could be used ethical resource - based learning, the activities of ethical resource based learning included: 1. provide content, resources and learning resources, 2. offer knowledge, skills, attitudes and experience to arouse interest for discussion of students, 3 . select ethical resource, 4. group process to study the area of ethical resource, the teacher's role to provide assistance and facilitate, 5. Discuss knowledge to apply with other situation, 6. Explore attitude for learning activities using ethical resource, 7. present a performance with multimedia and 8. Summarize and evaluation of activities group. 2) Overall ethical information literacy of experimental sample before undertaking teaching was high $(\bar{x}=3.56$, S.D. $=0.63)$, when evaluating the ethical information literacy after undertaking teaching was increase $(\bar{x}$ $=3.77$, S.D. $=0.74)$, and overall moral behavior of experimental sample before undertaking teaching was high $(\bar{x}=3.73$, S.D. $=$ 0.83), when evaluating the moral behavior after undertaking teaching was increase $(\bar{x}=3.91$, S.D. $=0.77)$.
\end{abstract}

Index Terms-Ethical resource base learning, ethical information literacy, moral behavior.

\section{INTRODUCTION}

The $21^{\text {st }}$ century skills are new future to develop the student as a quality person by learning process to the growth of individuals and society by knowledge transfer, training, workshops, cultural heritage, and enhancement academic progress. The knowledge comes from the social environment Learning factors contribute to individual lifelong learning. Education must be the key to all students to learn and develop themselves, and those considered to be most important. The education must encourage students to develop their full potential and natural [1]. Therefore, it is essential to prepare

Manuscript received October 13, 2016; revised March 23, 2017. This work was supported in part by Suan Dusit University Department of Research and Development.

Titiya Netwong is with Faculty of Science and Technology, Suan Dusit University, Thailand (e-mail: titiya_net@dusit.ac.th).

Ratchadaphorn Thirawan is with Faculty of Humanities and Social Science, Suan Dusit University, Thailand (e-mail: ratchadaphorn_thi@dusit.ac.th). students with the skills for living in the $21^{\text {st }}$ century, by learning the importance concept in the $21^{\text {st }}$ century. There are substance of content and three skills as follows: learning skills and innovation, media and technology literacy, and life skills and career to success in both work and life of students. That it will affect to features the work to adaptation, leadership, learning features, self direction, monitoring and their learning, features and moral [2], [3].

It was said that the strategy of teaching and learning in the 21 st century requires the integration of learning activities The students learn in practice. Teachers need to change the role of teaching presenters as a coaching and facilitator for the students to learn deeply. The instructors teach less but the students have learned more from the problems outside the classroom or community learning together as a team [4]. And assess the progress of their learning, what about self-esteem, and inspire them.

Ethical resources are source of moral knowledge that has been recognized in materials containing the wisdom to know and learn. A learning process brings awareness to the community and social development. The objective of ethical resources is the good values of self-reliance and supporting the society. This type of learning moral was classified by location into three types [5].

1) The temple, as a learning moral society with a long history in Thailand, centered learning link between home, school, and temple by a gauge at the center.

2) School or institution can be developed as a learning moral. In Thailand, there are the sufficiency economy school and institute to development of professional and ethics.

3) Community are ethical resources with the aim of creating a moral community to be strengthened. A center for the community participation in the development of sustainable communities was based on sufficiency economy philosophy and ethics.

The use of ethical resources base is an alternative teaching methods. Teachers can use to enhance the learning of students in the 21 st century. The activities include learning a variety of search sources. Seek resources that reinforce morality. Survey to study of learning, apply knowledge in other situations. Integration activities can be occurred in and outside the classroom. Over all activity that consistent with the goal of learning in the $21^{\text {st }}$ century requires that students have the knowledge, skills and characteristics. Education's big goal, preparing students to the world of work and civic life, learning for work and life in our times means helping as many students as possible learn to apply 21 st century skills and a solid understanding of core subjects to the challenge of our time [6], [7]. This style of teaching that will effectively 
contribute to sustainable development, ethical behavior is a mental and intellectual [8].

\section{MATERIALS AND MethodS}

\section{A. Subject Selection and Criterions}

The sample group to this study consisted of 38 undergraduate students enrolled in the Information Technology who registered the course of information integration in 2015 academic year.

\section{B. Instrument}

The research instruments were as follows:

1) The ethical information literacy questionnaire with 5 levels that perform highest, high, medium, few and least level.

2) The moral behavior questionnaire with 5 levels that perform highest, high, medium, few and least level.

\section{Research design}

One group pretest-posttest design was research design in this study

\section{$\mathrm{T}_{1} \times \mathrm{T}_{2}$}

\section{$\mathrm{X}$ : Experiment or Treatment}

$\mathrm{T}_{1}$ : Pretest

$\mathrm{T}_{2}$ : Posttest

\section{Statistic}

The statistical package was uses for mean, standard deviation, t-test dependent.

The meaning of ethical information literacy as follows: $4.21-5.00$ was the ethical information literacy level 5

$3.41-4.20$ was the ethical information literacy level 4

$2.61-3.40$ was the ethical information literacy level 3

$1.81-2.60$ was the ethical information literacy level 2 $1.00-1.80$ was the ethical information literacy level 1

The meaning of moral behavior as follows:

$4.21-5.00$ was the moral behavior level 5

$3.41-4.20$ was the moral behavior level 4

$2.61-3.40$ was the moral behavior level 3

$1.81-2.60$ was the moral behavior level 2

$1.00-1.80$ was the moral behavior level 1

\section{E. Methods}

The experimental group will learning by using ethical resource base learning for 8 weeks, the steps as follows:

Week 1: providing content, resources and learning resources.

Week 2: offer knowledge, skills, attitudes and experience to arouse interest for discussion of students.

Week 3: select ethical resource

Week 4: group process to studies the area of ethical resource, the teacher's role to provide assistance and facilitate.

Week 5: discussion knowledge in order to apply this knowledge in other situations.

Week 6: explores attitudes to learning activities using ethical resource.
Week 7: presents a performance with multimedia.

Week 8: summary and evaluation activities group.

\section{RESUlTS AND DiSCUSSION}

\section{A. Ethical Information Literacy}

Development of ethical information literacy could using by ethical resource-based learning. The students' ethical information literacy before and after undertaking ethical resource base learning was shown in Fig. 1.

ethical information literacy (mean)

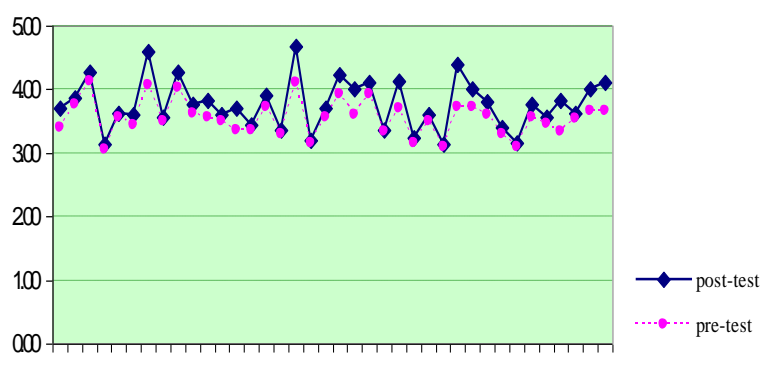

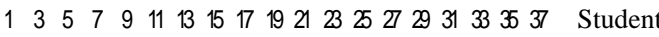

Fig. 1. The ethical information literacy before and after undertaking ethical resource based learning.

Fig. 1 is shown the ethical information literacy before and after undertaking ethical resource based learning of students. Ethical information literacy of everybody after treatment was higher than before treatment.

The comparison of the pre-test and post-test score by using the ethical information literacy was found at the significance level of 0.05 . The ethical information literacy before and after undertaking ethical resource base learning were different, shown in Table I.

TABLE I: THE ETHICAL INFORMATION LITERACY PRE-TEST AND POST-TEST

\begin{tabular}{|c|c|c|c|c|c|c|c|}
\hline \multirow[b]{2}{*}{ Item } & \multicolumn{3}{|c|}{ Pre-test } & \multicolumn{3}{|c|}{ Post-test } & \multirow[t]{2}{*}{ t-test } \\
\hline & $\bar{x}$ & S.D. & level & $\bar{x}$ & S.D. & level & \\
\hline $\begin{array}{l}\text { 1.Information } \\
\text { ethical } \\
\text { awareness }\end{array}$ & 3.51 & 0.61 & 4 & 3.78 & 0.73 & 4 & $0.00^{*}$ \\
\hline $\begin{array}{l}\text { 2. Information } \\
\text { ethical } \\
\text { evaluation }\end{array}$ & 3.58 & 0.58 & 4 & 3.75 & 0.69 & 4 & $0.00 *$ \\
\hline $\begin{array}{l}\text { 3. Application } \\
\text { of information } \\
\text { ethical }\end{array}$ & 3.59 & 0.69 & 4 & 3.78 & 0.74 & 4 & $0.00^{*}$ \\
\hline
\end{tabular}

\begin{tabular}{cccccccc}
\hline Over view & 3.56 & $\mathbf{0 . 6 3}$ & 4 & 3.77 & 0.74 & 4 & $0.00 *$ \\
\hline \hline${ }^{*} p<0.05$ & & & & & & &
\end{tabular}

Table I shown the ethical information literacy pre-test and post-test of students. Information ethical awareness post-test was highest. The components of Information ethical awareness were searching, analysis and integration of ethical information. Information ethical evaluation consisted of summary, benefit analysis, recheck and evaluate website of ethical information. And the components of application of information ethical were using ethical information to transfer, apply and create of ethical information. 


\section{B. Moral Behavior}

Development of moral behavior could using by ethical resource -based learning. The students' moral behavior before and after undertaking ethical resource base learning was shown in Fig. 2.

TABLE II: The MoRAL BeHAVIOR PRE-TEST AND POST-TEST

\begin{tabular}{|c|c|c|c|c|c|c|c|}
\hline \multirow[b]{2}{*}{ Item } & \multicolumn{3}{|c|}{ Pre-test } & \multicolumn{3}{|c|}{ Post-test } & \multirow[b]{2}{*}{ t-test } \\
\hline & $\bar{x}$ & S.D. & level & $\overline{\bar{x}}$ & S.D. & level & \\
\hline 1.Gratitude & 3.62 & 0.78 & 4 & 3.78 & 0.75 & 4 & $0.00^{*}$ \\
\hline 2.Honesty & 3.95 & 0.90 & 4 & 4.21 & 0.74 & 5 & $0.00 *$ \\
\hline 3.Discipline & 3.66 & 0.97 & 4 & 3.89 & 0.82 & 4 & $0.00^{*}$ \\
\hline 4.Responsibility (Perseverance) & 3.77 & 0.63 & 4 & 3.89 & 0.70 & 4 & $0.00 *$ \\
\hline 5.Sacrifice & 3.65 & 0.81 & 4 & 3.78 & 0.75 & 4 & $0.00 *$ \\
\hline Over view & 3.73 & 0.83 & 4 & 3.91 & 0.77 & 4 & $0.00 *$ \\
\hline
\end{tabular}

$* p<0.05$

moral behavior (mean)

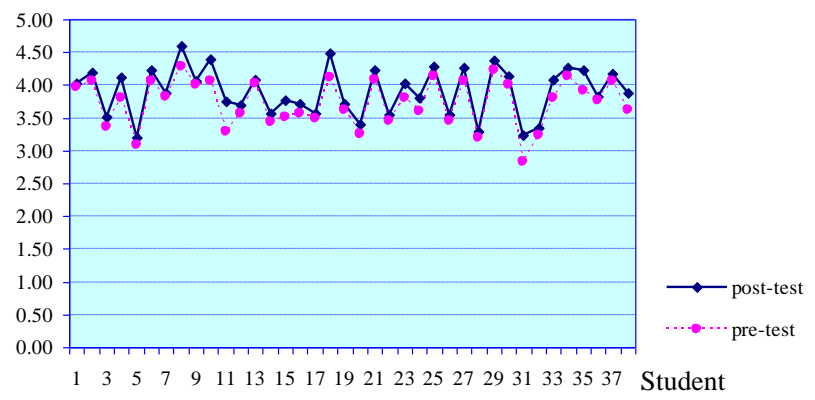

Fig. 2. The moral behavior before and after undertaking ethical resource.

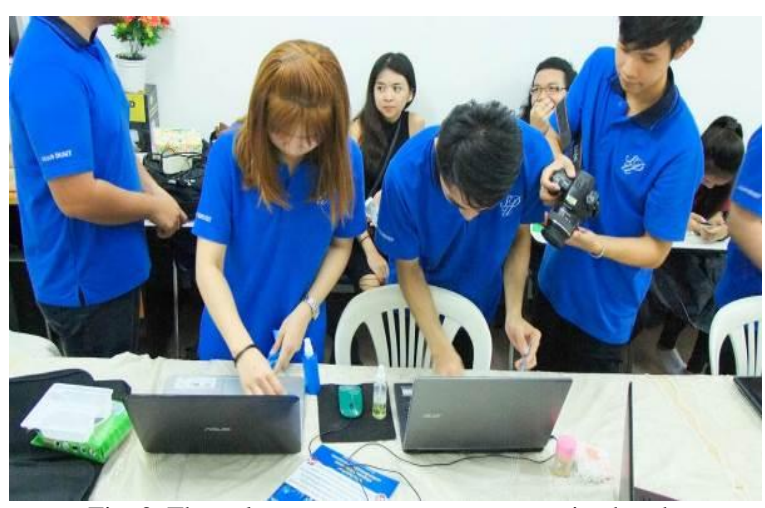

Fig. 3. The volunteer to renovate computer in church.

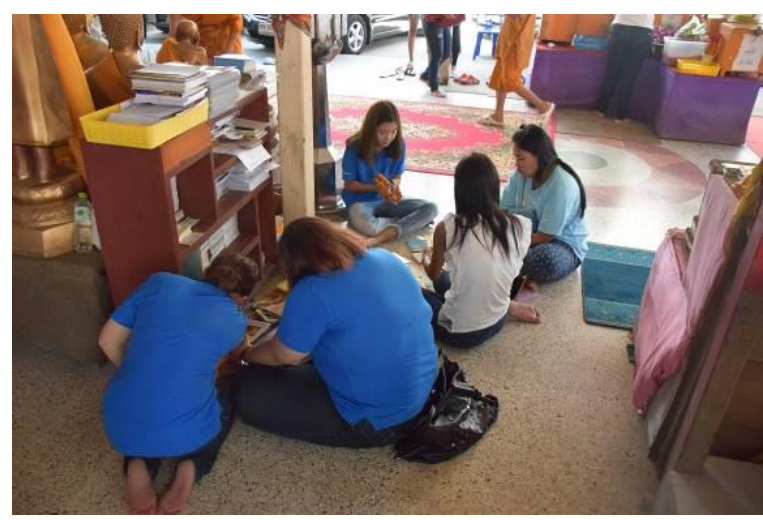

Fig. 4. The volunteer to repair book in Prayasurain temple.

Fig. 2 is shown the moral behavior before and after undertaking ethical resource based learning of students. Moral behavior of everybody after treatment was higher than before treatment.

The comparison of the moral behavior of the experiment between the pre-test and post-test was at the significance level of 0.05 . The moral behavior before and after undertaking ethical resource base learning were different, shown in Table II.

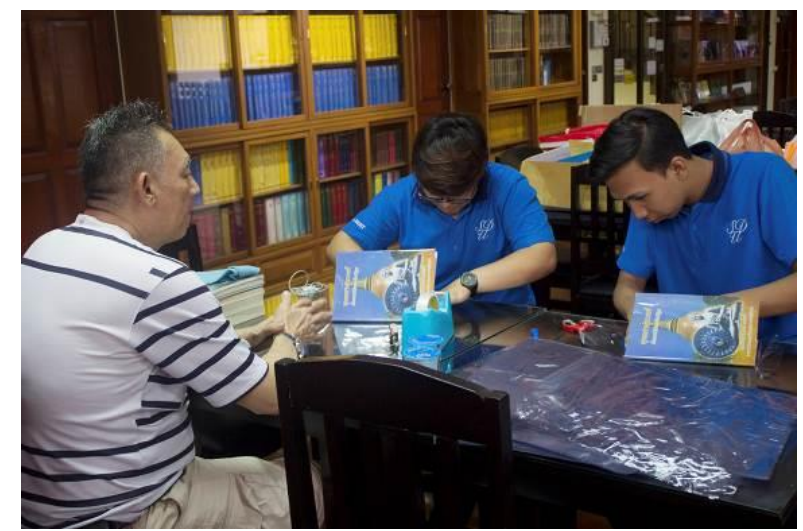

Fig. 5. The volunteer to repair book in Duang-kae temple.

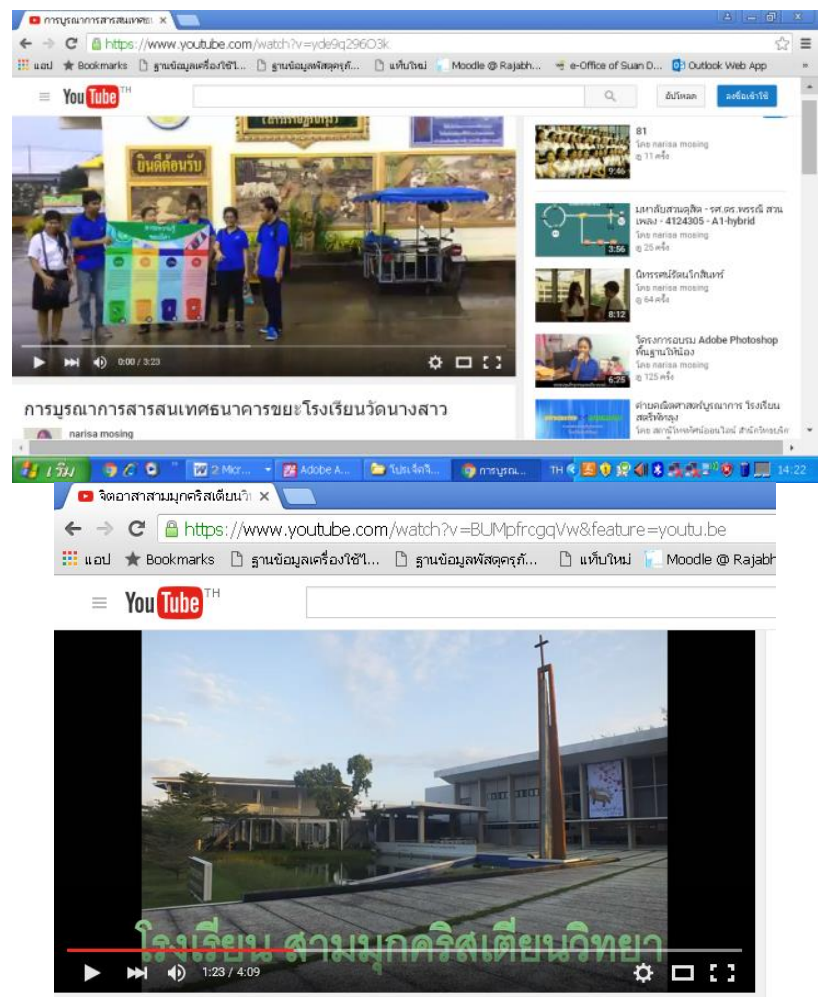

Fig. 6. The activities of ethical resource base learning up load to YouTube.

Table II shown the moral behavior pre-test and post-test of students. The means of Honesty post-test were highest, and the next were Responsibility (Perseverance), Discipline, Gratitude and Sacrifice. 


\section{CONCLUSION}

The development of learners in the 21 st century requires a process of teaching a wide variety. Instructors use teaching techniques that focus on the process that leads the students to learn on their own and the opportunities for learners' curiosity. The self-directed of them and find resources for research knowledge [8]. Integration of learning activities similar to the life skills of learners in the 21 st century both in terms of knowledge of the subject matter and knowledge integration. The skills needed for learning and life skills as well as learning and innovation, life skills and work, and media and technology literacy. This will affect the students to promote learning and lifestyle appropriately. And this includes both of features work, learning and moral. So the teaching and learning by using an ethical resources base to learn is how to teach the lesson that can be used in the teaching process. To encourage students to build knowledge from the experience gained from the learning virtues. Learning activities to focus on the learners in the $21^{\text {st }}$ century is able to survive the global community to their full potential. This is consistent with Office of the National Anti-Corruption [9] that support from the government encourages people to Thailand are honest. The establishment of the Museum and the National Anti-Corruption (Anti-Corruption Museum), a learning center on prevention and combating corruption help a society free of corruption and transparent Thailand enhances the students to gain the honesty.

\section{APPENDIX}

The activities of ethical resource base learning are shown in Fig. 3-6.

\section{REFERENCES}

[1] Office of the Education Council. (2016). Nation Education (No.3) 2010. [Online]. Available: http://www.onec.go.th/onec_web/ page.php?mod=Category\&categoryID=CAT0000011
[2] J. Bellanca and R. Brandt, $21^{\text {st }}$ Century Skills: Rethinking How Students Learn, Tree Press, 2010.

[3] Office of the Basic Education Commission, Guidelines for $21^{\text {st }}$ Century to Learning Skills Focus on Professional Performance, Upper Secondary Education Office of the Basic Education Commission.

[4] T. Netwong, "Development of information technology literacy and volunteers by using blended learning and society service project based learning," Journal of Industrial Education, vol. 13, no. 3, pp. 59-65, 2014.

[5] Moral Promotion Cente, Development of Moral Learning Resource, Bangkok: Moral Promotion Center (Public Organization), 2014.

[6] S. Intharat et al., "The effectiveness of an approach to integrate ethics into information technology by following sufficiency economy philosophy, Suan Dusit Rajabhat University," Journal of Industrial Education, vol. 13, no. 3, pp. 113-119, 2014

[7] B. Trilling and C. Fadel, 21 ST Century Skills: Learning for Life in Our Times, San Francisco: Jossey-Bass A Wiley Imprint, 2009.

[8] K. Boonphak, "Skill and technical learning management to excellence," Journal of Industrial Education, vol. 14, no. 1, pp. 1-4, 2015.

[9] Office of the National Anti-Corruption. (2016). Public Relations News. [Online]. https://www.nacc.go.th/ewt_news.php?nid=11609

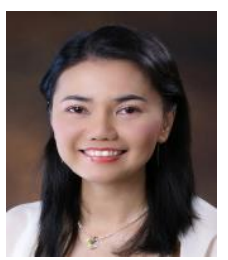

T. Netwong was born in Kalasin province, Thailand. She completed her doctor of philosophy degree in educational communications and technology in 2010 . She is a lecturer at the Faculty of Science and Technology, Suan Dusit University in Thailand.

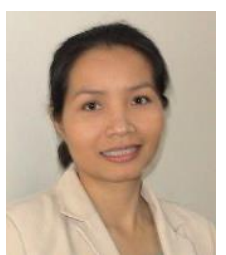

R. Thirawan was born in Sakonnakhon province, Thailand. She completed her master of arts degree in library and information science in 1996 and the master of arts degree in buddhist studies on 2016. She is a lecturer at the Faculty of Humanities and Social Science, Suan Dusit University in Thailand. 